\title{
SOURCES AND TRANSFORMATION OF DISSOLVED ORGANIC CARBON IN THE HARP LAKE FORESTED CATCHMENT: THE ROLE OF SOILS
}

\section{S. E. TRUMBORE}

Center for Accelerator Mass Spectrometry, Lawrence Livermore National Laboratory, Livermore California 94550 USA

\section{S. L. SCHIFF, RAMON ARAVENA and RICHARD ELGOOD}

Center for Groundwater Research, University of Waterloo, Waterloo, Ontario N2J 3E6 Canada

\begin{abstract}
The ${ }^{14} \mathrm{C}$ content of dissolved organic carbon (DOC) in streams, soil water and groundwaters in the Harp Lake catchment in Ontario, Canada, reflect a mixture of DOC sources, including both contemporary plant material and ${ }^{14} \mathrm{C}$ depleted soil organic matter. The concentration and isotopic content of DOC in streams is highly variable, reflecting the complex flow path of the source water entering the streams. The characteristics of groundwater DOC are set in the soil column, either through DOC production in the deeper soil layers, or through preferential decomposition and/or sorption of ${ }^{14} \mathrm{C}$-enriched DOC components from percolating waters. We estimate the relative magnitudes of decomposition, transport and sorption as sinks for DOC produced in forested catchment soils.
\end{abstract}

\section{INTRODUCTION}

Dissolved organic carbon (DOC) is operationally defined as the organic carbon in solution that passes through a $0.45 \mu$ filter. Although its concentration in streams and groundwaters is low, $1-10$ $\mathrm{mg} \mathrm{C}$ liter $^{-1}$, DOC plays an important role in carbon cycling, acid-base and trace-metal chemistry in forested catchments. Laboratory studies have shown that $25 \%$ to nearly $50 \%$ of the annual loss of carbon in forest-floor detrital layers may be due to production and leaching of DOC (Cronan 1985; Vance \& David 1991). As many nutrients and trace elements, including pollutants, complex with DOC, the mobility, toxicity and fate of these elements within the soil profile and the catchment will be tied to DOC cycling (Stevenson 1982). Dissolved organic acids can contribute to the acidity of natural waters (LaZerte \& Dillon 1984). Because of the hypothesized competition for sorption sites in soil between organic acid anions and $\mathrm{SO}_{4}^{2-}$ (LaZerte \& Dillon 1984), DOC also plays a role in the acid-base balance and exchange capacity in the soil. The transport of DOC from detrital layers may play an important role in the input and accumulation of organic carbon in forest soils.

Despite its importance, relatively little is known of the sources, transformation and ultimate fate of DOC in natural waters. Carbon isotopes are particularly important tools in the study of DOC in this context (Murphy et al. 1989; Schiff et al. 1990; Wassenaar et al. 1990, 1991a, 1991b). The ${ }^{13} \mathrm{C}$ content of DOC can aid in identifying the processes that create and consume DOC. The ${ }^{14} \mathrm{C}$ content, particularly the degree to which ${ }^{14} \mathrm{C}$ derived from atmospheric weapons testing ('bomb' ${ }^{14} \mathrm{C}$ ) is present, yields information about both the sources and the rate of turnover of DOC.

We report results of an ongoing project using carbon isotopes to study carbon cycling in a small forested catchment in central Ontario (see also Schiff et al. 1990; Aravena et al. 1992). We compare ${ }^{14} \mathrm{C}$ measurements of stream, soil water and groundwater DOC to the ${ }^{14} \mathrm{C}$ content in soil organic matter (SOM), and in organic carbon leached from soils. From these measurements, we infer the major controls of DOC production and cycling in the Harp Lake catchment.

${ }^{1}$ Present Address: Department of Geosciences, University of California-Irvine, Irvine, California 92717 USA 


\section{FIELD AREA}

The results presented here are part of a larger, ongoing study of the carbon cycle in soft-water lakes using carbon isotopes (Schiff et al. 1990; Aravena and Schiff, 1991; Aravena et al. 1992). Harp Lake catchment is a small forested watershed located in the District of Muskoka, Ontario, Canada. The location, morphology and instrumentation of the Harp Lake catchment are described in Aravena et al. (1992). Figure 1 shows the location of Harp Lake and identifies the streams discussed in this paper. The vegetation in the watershed is mixed deciduous-conifer forest, and the soils are predominantly weakly developed Spodosols. The soils are developed on glacial till deposits overlying Precambrian Shield bedrock. Groundwaters are located within the till deposits. Since 1988, we have sampled DOC and DIC in lake, stream and groundwaters for C isotopic analyses. In this paper, we discuss data from streams and groundwater. The DOC budget for the whole watershed, including the lake, is discussed in Schiff et al. (1990).

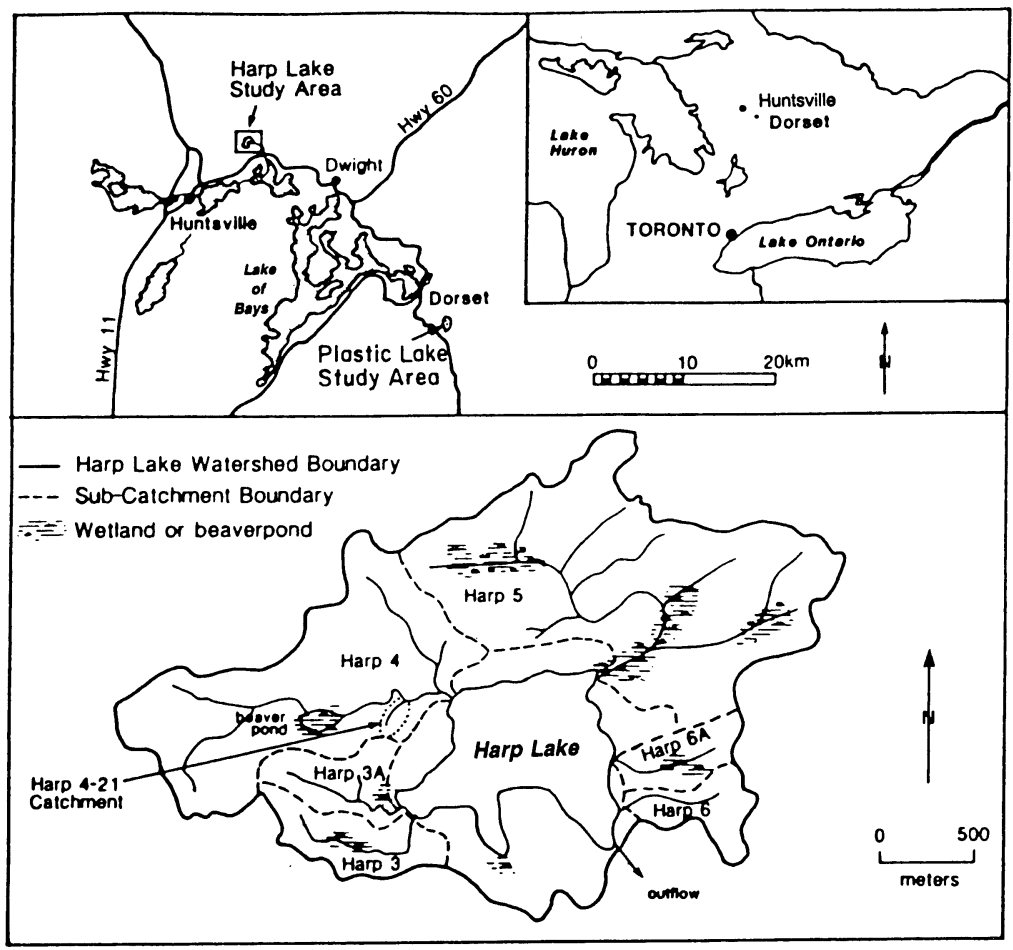

Fig. 1. Location of the Harp Lake watershed and streams discussed in this paper

Schiff et al. (1990) describe the collection and preparation of DOC samples for carbon isotope analysis from lysimeters, streams and groundwaters. In brief, water samples were freeze-dried, and the organic residue combusted. The resulting $\mathrm{CO}_{2}$ was cryogenically purified, then reduced to graphite for accelerator mass spectrometric (AMS) determination of ${ }^{14} \mathrm{C}$ according to the method described in Vogel, Nelson and Southon (1987). Most of the AMS measurements were made at the Lawrence Livermore National Laboratory (LLNL) Center for Accelerator Mass Spectrometry (Davis et al. 1990); a few, also reported in Schiff et al. (1990), were measured at the PSI/ETH accelerator facility in Zürich, Switzerland. We report ${ }^{14} \mathrm{C}$ results in $\Delta$ notation (Stuiver \& Polach 1977), corrected for fractionation using either measured $\delta^{13} \mathrm{C}$ (particulate and most DOC), or assuming $\delta^{13} \mathrm{C}$ values of $-25 \%$ (leached organics). The accuracy of the $\Delta^{14} \mathrm{C}$ measurements at 
LLNL is equivalent to $\pm 15 \%$. Additional uncertainty of up to $10 \%$ may be present due to incorrectly assumed $\delta^{13} \mathrm{C}$ values.

Samples of surface detrital layers and mineral soil A and B horizons were collected in October, 1990 from pits dug in the Harp 4-21 subcatchment. Soil samples were stored frozen or refrigerated, and were not dried or sieved prior to leaching. Carbon isotopic analyses and leaching studies were performed on two detrital layers (LF1 and LF2), and on intervals of $0-5$ and 5-10 $\mathrm{cm}$ (A horizon), and 10-25 and 25-40 cm (B horizon) from one pit (Soil \#1). Results will also be discussed from a second, deeper, soil pit (Soil \#2), located at a higher elevation in the subcatchment, though a similar distance from the stream.

\section{RESULTS}

\section{DOC in Surface, Soil and Groundwaters}

Figure 2 shows the range of the DOC concentrations (left panel), and $\delta^{13} \mathrm{C}$ (center) and $\Delta^{14} \mathrm{C}$ (right) contents of DOC measured in streams in the Harp Lake watershed during 1989-1990. Data shown are for streams draining predominantly upland areas: Harp 4, 3A, and Harp 4-21, the stream closest to the soil sampling area (see Fig. 1). Data from lysimeters and groundwater wells (mid-screen depths indicated) located in the Harp 4-21 subcatchment are also plotted. Wells 59 through 63 in Figure 2 are from the same elevation as the soil pit (Soil \#1), but are located closer to the stream bed of Harp 4-21. Wells 50 and 55 are located downstream, near the lake edge. The lysimeter nests sampled for DOC are located downslope of Soil \#1.
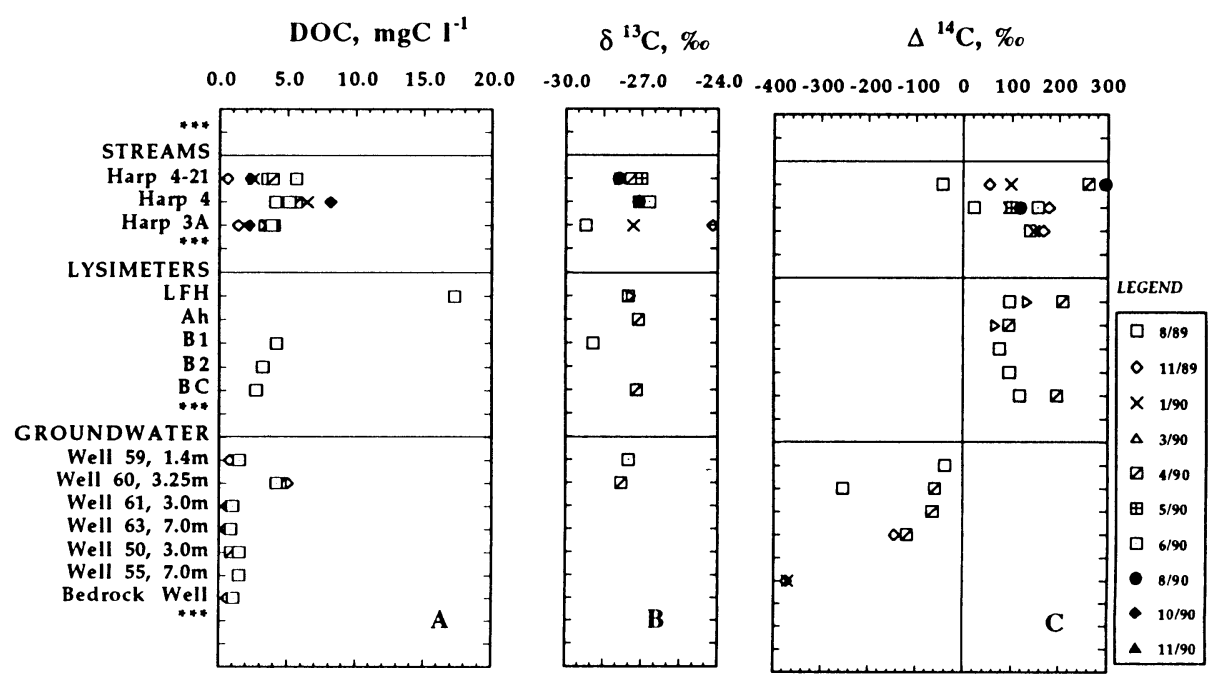

Fig. 2. Concentration (A), ${ }^{13} \mathrm{C}(\mathrm{B})$ and ${ }^{14} \mathrm{C}(\mathrm{C})$ content of DOC collected during 1989-1990 from streams, lysimeters (by horizon sampled) and groundwater wells located in the Harp Lake catchment

The data plotted in Figure 2 support observations first made in Schiff et al. (1990): 1) the ${ }^{14} \mathrm{C}$ content of stream DOC reflects the presence of significant (in most cases $>50 \%$ ) bomb ${ }^{14} \mathrm{C} ; 2$ ) a dramatic decrease in the ${ }^{14} \mathrm{C}$ content of DOC between streams and groundwater. The addition of more data from detailed sampling over one seasonal cycle demonstrates the large variability in the concentration and ${ }^{14} \mathrm{C}$ content of DOC in streams. DOC concentrations vary between 1 and $8 \mathrm{mg}$ $\mathrm{C}$ liter $^{-1}$ in the upland streams, with little identifiable seasonal trend. Highest DOC concentrations 
are observed in zero-tension lysimeters installed in the soil litter layer (LFH on Fig. 2). Groundwater DOC concentrations, with the exception of Well 60, are less than $2 \mathrm{mg} \mathrm{Cliter}{ }^{-1}$. The $\delta^{13} \mathrm{C}$ content of DOC for streams, lysimeter and groundwaters generally fall between $-27 \%$ and $-28 \%$ (PDB).

The $\triangle^{14} \mathrm{C}$ of DOC from streams is, with one exception, always positive, indicating the presence of bomb-produced ${ }^{14} \mathrm{C}$. Although upland stream values generally are less than those contained in leaves sampled in 1990 (175 $\pm 10 \%$; Aravena et al. 1992), DO ${ }^{14} \mathrm{C}$ values in stream Harp 4-21 have been measured as low as $-40 \%$ and as high as $+280 \%$. These extreme ${ }^{14} \mathrm{C}$ values both indicate the importance of 'older' carbon sources for DOC. To produce $\mathrm{DO}^{14} \mathrm{C}$ values less than $0 \%$, organic matter formed before 1960 must predominate in the mixture of components that produce the bulk isotopic composition. $\mathrm{DOC}$ with ${ }^{14} \mathrm{C}$ contents greater than present atmospheric values indicate the influence of carbon derived from plant material formed 10-30 years ago. The large variations seen in Figure 2 imply changes in the DOC concentration and $\mathrm{DOC}{ }^{14} \mathrm{C}$ activity in the sources of stream water, probably controlled by interactions between water and SOM. No seasonal trend is discernible from the available data. The ${ }^{13} \mathrm{C}$ and ${ }^{14} \mathrm{C}$ contents of DOC in streams are not correlated.

In contrast, the ${ }^{14} \mathrm{C}$ contents of DOC from shallow $(<7 \mathrm{~m})$ groundwaters in tills underlying the soils, are all significantly less than $0 \%$. The numbers closest to $0 \%$ are observed in shallow wells sampled during high water-table conditions. The $\Delta^{14} \mathrm{C}$ of dissolved inorganic carbon (DIC) in the same wells are all close to contemporary atmospheric values (Aravena et al. 1992), suggesting that the residence time for groundwaters in the catchment is less than $30 \mathrm{yr}$. Dankevy et al. (1990) estimated a groundwater residence time in the Harp 4-21 subcatchment of $4 \mathrm{yr}$, based on ${ }^{3} \mathrm{H}$ measurements and hydrologic modeling. Thus, the depletion of ${ }^{14} \mathrm{C}$ in groundwater $\mathrm{DOC}$ reflects the source of the DOC: it is not an effect of 'aging' in an isolated water mass. Interaction of DOC in percolating waters with the soil column must play a role in setting the character of groundwater DOC.

Figure 2 also shows measurements of DOC sampled from zero-tension lysimeters installed in the Harp 4-21 watershed. The lysimeters are located upstream and upslope of the soil pits used in this study. DOC concentrations are highest in the detrital layer ( $\mathrm{LFH})$, and decrease through the $\mathrm{A}(\mathrm{Ah})$ and $\mathrm{B}(\mathrm{B} 1, \mathrm{~B} 2, \mathrm{BC})$ horizons. $\Delta^{14} \mathrm{C}$ values are, in all cases, positive, with no consistent difference in the ${ }^{14} \mathrm{C}$ content of DOC collected by the lysimeters in different soil horizons. The data are limited, and may be misleading, because the zero-tension lysimeters collected only sufficient water for the ${ }^{14} \mathrm{C}$ measurement during high flow periods. The water flow path in the shallow part of the soil is complex because of the heterogeneity of the tills. Thus, it is possible that they are collecting a mixture of groundwater and recharge water that flows laterally through the shallow (organic-rich) part of the soil toward the lysimeters.

\section{Soil Organic Matter and Leachates}

To explore the possible sources of DOC depleted in ${ }^{14} \mathrm{C}$ to the stream water, to understand the decrease in DOC concentration and ${ }^{14} \mathrm{C}$ content between surface and groundwater, and to avoid the sampling problems involved with lysimeters, we performed laboratory leaching experiments on soil samples. Between 20-90 g litter or soil was gently agitated in a beaker with $200 \mathrm{cc}$ of deionized water. Particles were allowed to settle for $24 \mathrm{~h}$; then the water, containing soluble organic matter, was decanted and passed through a precombusted glass fiber filter. The wet soil was rinsed once by adding more distilled $\mathrm{H}_{2} \mathrm{O}$, and repeating the settling and filtration procedures. The filtered solution was evaporated to near dryness in an oven kept at $60^{\circ} \mathrm{C}$. The organic residue was resuspended with a few $\mathrm{ml}$ of distilled water, transferred to a preweighed, precombusted 10-cc glass test tube and vacuum dried. The residue was weighed and an aliquot combusted at $900^{\circ} \mathrm{C}$ in an evacuated quartz tube in the presence of $\mathrm{CuO}$ wire (Boutton et al. 1983). The calculation of DOC yield 
from each soil layer was based on the quantity of $\mathrm{CO}_{2}$ produced by combustion of the dried filtrate and the dry weight and carbon content of the extracted soil (also determined by $\mathrm{CO}_{2}$ evolution on combustion). The results are expressed as the percent of the total available soil carbon leached.

Figure $3 \mathrm{~A}$ shows the percent of the total organic carbon solubilized by the leaching procedure, together with the residual soil carbon content (expressed as $\mathrm{g} \mathrm{C} \mathrm{m}^{-2} \mathrm{~cm}^{-1}$ depth in the soil). To calculate inventories of soil carbon, we estimated bulk density values using the relations given in Zinke et al. (1984). The depth ranges of litter (L), A (A1 and A2) and B (B1 and B2) horizons are identified. The increase in the soil organic carbon content in the B horizon is one characteristic of Spodosols, and is usually assumed to be due to the accumulation of organic carbon leached from the A horizon and detrital layers (Brady 1983). The neutral leach solubilized the most organic carbon (4.5 and $1.2 \%$ of the total available carbon) from the LF1 and LF2 detrital layers. The amount of DOC produced decreased substantially in the mineral soil, $<0.2 \%$ of the carbon inventory in the A horizon and $<0.02 \%$ in the B horizon. The amounts of leached organic carbon are not directly interpretable as concentrations of DOC in percolating waters or fluxes of DOC.

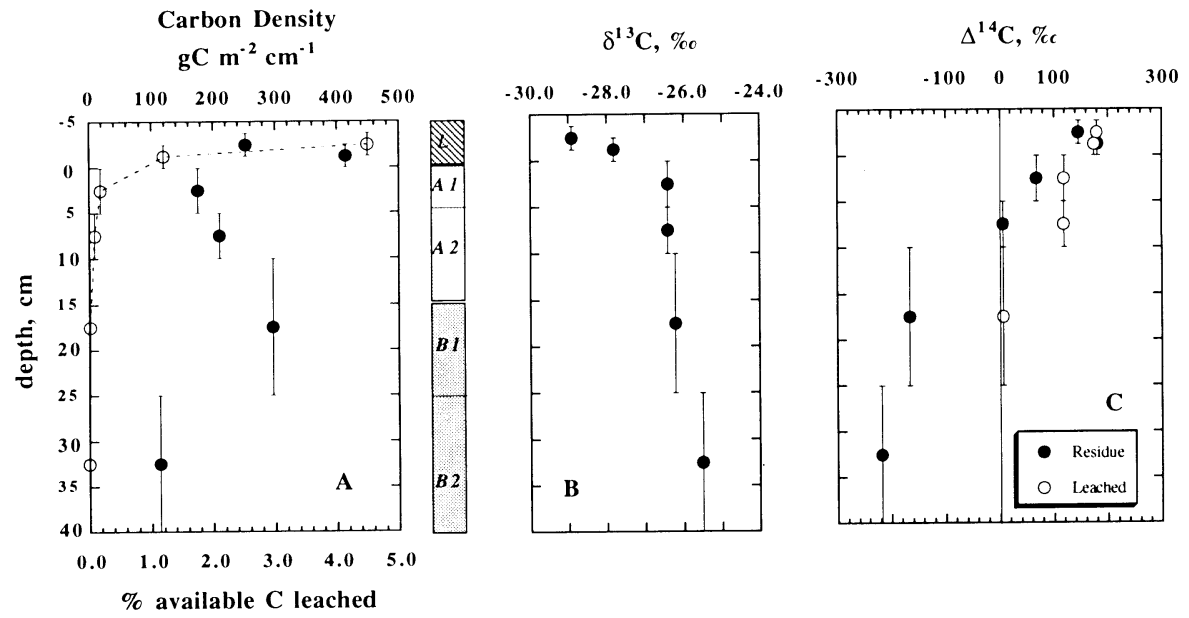

Fig. 3. (A) The amount of carbon solubilized by the neutral leach ( $\circ$, expressed as $\%$ of the total soil carbon), and the carbon content of SOM remaining after the leaching process $\left(\mathrm{g} \mathrm{C} \mathrm{m}^{-2} \mathrm{~cm}^{-1}\right.$ depth in the soil; $\left.\bullet\right)$. Points are located at the mid-depth of the sampling interval. 'Error bars' show the extent of the depth interval sampled. (B) ${ }^{13} \mathrm{C}$ content of particulate soil organic carbon. (C) ${ }^{14} \mathrm{C}$ content of soluble and residual particulate organic carbon.

Figures $3 \mathrm{~B}$ and $3 \mathrm{C}$ show the carbon isotopic content $\left(\delta^{13} \mathrm{C}\right.$ and $\left.\Delta^{14} \mathrm{C}\right)$ of the SOM and organic carbon solubilized in the leaching process. $\delta^{13} \mathrm{C}$ determinations are only available for the particulate (residual) organic carbon. The ${ }^{13} \mathrm{C}$ contents of fresh plant material, and relatively undecomposed litter (LF1), with $\delta^{13} \mathrm{C}$ of -28 to $-30 \%$, are more depleted than the average $\delta \mathrm{DO}^{13} \mathrm{C}$ of $-27 \%$ observed in streams, lysimeters and groundwaters (Fig. 2). Mineral SOM was more enriched in ${ }^{13} \mathrm{C}$ $\left(>-26 \%\right.$ ) than DOC in surface, soil and groundwaters. This trend in ${ }^{13} \mathrm{C}$ is due to decomposition of organic matter in the shallow part of the soil and subsequent transport downward through the soil column (Nadelhoffer \& Fry 1988). The $\Delta^{14} \mathrm{C}$ of the leached and particulate organic carbon in litter horizons were all close to ${ }^{14} \mathrm{C}$ values for leaves grown in $1990(+175 \pm 10 \%$ ). Soil organic carbon and leachates from the $\mathrm{A}$ horizon also had positive $\Delta^{14} \mathrm{C}$ values, though significantly less than those in the litter layers. The $\Delta^{14} \mathrm{C}$ of DOC leached from the $\mathrm{B} 1$ horizon $(10-25 \mathrm{~cm})$ was $+10 \%$ (neutral), whereas the particulate carbon in both $B$ horizons $(10-25$ and $25-40 \mathrm{~cm}$ ) were $<-150 \%$. Insufficient organic carbon was leached from the $25-40 \mathrm{~cm}$ layer to measure the ${ }^{14} \mathrm{C}$ 
content. Soluble organic carbon was enriched in ${ }^{14} \mathrm{C}$ relative to the residual particulate SOM in A and $\mathrm{B}$ horizons; the difference between leached and residual ${ }^{14} \mathrm{C}$ increased with depth in the mineral soil (Fig. 3C).

Acidification of the B horizons of forest soils releases organic matter into solution (Jardine, Weber \& McCarthy 1989). Thus, increased mobilization of DOC may be one response of forested catchment soils to acidification. Due to the importance of acidification in the region surrounding the Harp Lake watershed, and because the yield of DOC in neutral solution leaches was insufficient to measure ${ }^{14} \mathrm{C}$ in the $\mathrm{B} 2$ horizon, we acidified the leaching solution. Samples from the B horizon of a second soil (Soil \#2), located at greater elevation, but similar distance upslope from Soil \#1, were leached with dilute acid. Leaching procedures were the same as those described above, except that the leaching solution was acidified to $\mathrm{pH} 2$ with $\mathrm{HCl}$. The $\Delta^{14} \mathrm{C}$ of the total freeze-dried solubilized organic matter was $-200 \pm 12 \%$ (B2, Soil \#2), and $-340 \pm 10 \% \circ$ (BC, Soil \#2). DOC was also leached with acidified solution from the $25-40 \mathrm{~cm}$ (B2) layer of Soil $\# 1$. We separated the acid soluble organic carbon from this soil into molecular weight fractions of $>100$ kdaltons and 3-100 kdaltons using ultracentrifugation. The $\Delta^{14} \mathrm{C}$ of the two molecular weight components were $-185 \pm 10 \%$ and $-155 \pm 10 \%$, respectively. The amount of carbon solubilized in acidic solution is an artifact of the $\mathrm{pH}$ and amount of solution used; different treatment (e.g., heating, sonication, increased or decreased acidity of solution) could have led to different results. The main point here is that acidification of the B2 horizon solubilizes carbon with ${ }^{14} \mathrm{C}$ contents that are significantly depleted, with respect to those in litter or A horizon SOM and leachates. This suggests that organic matter derived from the $\mathrm{B}$ horizon may be the source of the depleted ${ }^{14} \mathrm{C}$ observed in groundwater DOC.

\section{DiscusSion}

\section{Role of DOC in the Watershed Carbon Cycle}

The possible sources of DOC are soluble by-products of microbial activity, root exudates and chemical or biological breakdown of soil (or suspended particulate) organic matter. The carbon isotope signature of DOC derived from these sources will reflect the substrate: contemporary plant matter for root exudates and dead roots, or SOM (microbial decomposition). DOC produced in the Harp Lake catchment may have one of several fates, including (microbially mediated) remineralization, sorption on mineral surfaces and transport out of the watershed. Although a thorough, quantitative understanding awaits coupling of chemical and hydrological data, we may use the data presented here to infer the major source and sink processes affecting DOC in the Harp Lake watershed.

\section{Sources of DOC}

The ${ }^{14} \mathrm{C}$ content of DOC in streams (Fig. 2) reflects a mixture of sources, including both contemporary vegetation and decomposition of 'older' organic matter. The total production rate of DOC in the Harp Lake catchment may be estimated from the annual rate of input of new organic carbon to litter and soil layers, an assumption of steady state (annual input = annual decomposition) and the fraction of decomposition that produces DOC.

Assuming that the forest soil is in steady state (neither accumulating nor losing carbon with time), the rate of decomposition of carbon equals the inventory, $1.68 \mathrm{~kg} \mathrm{C} \mathrm{m}^{-2}$, times the rate of turnover. The carbon inventory was calculated from the measured carbon content and bulk density (calculated using formulae given in Zinke et al. 1984) for Soil \#1. We may estimate the rate of turnover from the amount of bomb ${ }^{14} \mathrm{C}$ in the soil detrital layers. A minimum estimate of soil car- 
bon turnover rates may be obtained by determining the fraction of soil carbon having the average $\Delta{ }^{14} \mathrm{C}$ of the atmosphere during the period, $1960-1990(+390 \%)$. Calculated this way, $37-46 \%$ of the carbon in the litter layers, $18 \%$ in the $\mathrm{A} 1$ horizon and $2 \%$ in the $\mathrm{A} 2(5-10 \mathrm{~cm})$ have been replaced with carbon labeled with bomb ${ }^{14} \mathrm{C}$ in the past $30 \mathrm{yr}$. As the $\Delta{ }^{14} \mathrm{C}$ of litter layer material is close to atmospheric values, a maximum turnover rate of less than $5 \mathrm{yr}$ ( $>20 \%$ turnover per year) may be ascribed to this layer. The annual rate of input of new organic carbon is, then, roughly $40 \%$ in $30 \mathrm{yr}\left(0.013 \mathrm{yr}^{-1}\right)$ to $95 \%$ per year $\left(0.95 \mathrm{yr}^{-1}\right)$ or 20 to $1500 \mathrm{~g} \mathrm{C} \mathrm{m}^{-2} \mathrm{yr}^{-1}$. Laboratory experiments (Vance \& David 1991) and field observations (Cronan 1985) have shown that DOC production accounts for between 25 and $50 \%$ of the total annual loss of forest floor material. The remaining $50-75 \%$ is converted directly to $\mathrm{CO}_{2}$. Assuming the same proportions apply in Harp Lake, the production rate of DOC from litter layers is between 5 and $750 \mathrm{~g} \mathrm{C} \mathrm{m}^{-2} \mathrm{yr}^{-1}$. As above and below ground detrital inputs for cool, temperate, deciduous forests are between 5 and 7 tons dry matter ha $\mathrm{h}^{-1} \mathrm{yr}^{-1}$ (roughly $250-350 \mathrm{~g} \mathrm{C} \mathrm{m}^{-2} \mathrm{yr}^{-1}$, assuming organic matter is 50\% C; Reiners 1973), the most likely estimate for turnover rate is in the middle of the range calculated from bomb ${ }^{14} \mathrm{C}$.

\section{Transport}

The Harp Lake watershed is a net exporter of DOC (Schiff et al. 1990). The total annual transport of DOC down the Harp 4 stream is $4.11 \times 103 \mathrm{~kg} \mathrm{C} \mathrm{yr}^{-1}$ (Schiff et al. 1990). Assuming the Harp 4 catchment contains $25 \%$ of the total watershed area $(0.25 \times 506 \mathrm{ha})$, the net production of DOC in upland watersheds that ends up in the stream is $0.0032 \mathrm{~kg} \mathrm{C} \mathrm{m}^{-2} \mathrm{yr}^{-1}\left(3.2 \mathrm{~g} \mathrm{C} \mathrm{m}^{-2} \mathrm{yr}^{-1}\right)$. Although DOC is also exported in groundwaters, the flux will probably be lower due to the low DOC concentrations in groundwater.

\section{Sorption}

The dominant process by which organic carbon, aluminum and iron accumulate in the B horizon of Spodosols is generally assumed to be through transport in solution from surface layers followed by sorption and precipitation (Dawson, Ugolini \& Fasth 1978; Brady 1984). Sorption and desorption exchange equilibria are determined by many factors, including soil mineralogy, organic carbon content, solution pH and sorption kinetics (Nodvin, Driscoll \& Likens 1986; Jardine, Weber \& McCarthy 1989). If the source of organic matter in the B horizon of Harp Lake soils is primarily the accumulation of leachates from the $\mathrm{A}$ and litter horizons, we may estimate magnitude of the sink for DOC by sorption. The rate of input of DOC to the B horizon may be estimated from the age of the soil (14 ka, because it is developed on glacial debris), and the present carbon and ${ }^{14} \mathrm{C}$ contents of the B horizon SOM. We assume that: 1) accumulation of DOC leached from the surface horizons is the main process causing carbon accumulation in the B horizon; 2) the carbon added by this process has a ${ }^{14} \mathrm{C}$ content reflecting atmospheric $\mathrm{CO}_{2} ; 3$ ) the rate of input of new material from overlying layers is constant over the past $14 \mathrm{ka}$; 4 ) the rate of decay of organic matter in the B horizon is first order (i.e., proportional to the amount of organic matter present), and may be described with one, average, decay constant; 5) initial $\mathrm{C}$ and ${ }^{14} \mathrm{C}$ contents of the soil $14 \mathrm{ka}$ ago were zero. Assumption (1) is basic to the nature of Spodosols, and (2) reflects the fact that the highest observed concentration of DOC is in the litter layer, where leachable organic carbon is contemporary. Assumptions (3) and (5) are based on the idea that development of vegetation following glaciation is rapid compared to the development of the soil, and on the chronosequence studies of Spodosol pedogenesis by Chandler (1942). Assumption (4) is discussed below.

The amount of carbon in the B horizon at time, $t$, is described as 


$$
C(t)=\frac{I}{r_{d}}\left[1-\exp ^{-r_{d} t}\right]
$$

where $I$ is the annual input rate of fresh organic material, and $r_{d}$ is the average first-order decay constant for the organic matter. The radiocarbon age of the SOM at time, $t$, is then

$$
\text { Age }=-8033 \ln \left(\frac{R C(t)}{C(t)}\right)=\frac{\frac{I}{r_{d}+r_{14}}\left[1-\exp ^{-\left(r_{d}+r_{14}\right) t}\right]}{\frac{I}{r_{d}}\left[1-\exp ^{-r_{d} t}\right]}
$$

where $\mathrm{RC}(\mathrm{t})$ is the inventory of ${ }^{14} \mathrm{C}$ at time, $t$, and $\mathrm{r}_{14}$ is the decay constant for radiocarbon $(1 / 8270$ $y r)$. For any given time, $t$, if the carbon and ${ }^{14} \mathrm{C}$ content of the soil are known, Equations (1) and (2) may by solved for I. For the Harp Lake soil B horizon, $t$ may be estimated as $14 \mathrm{ka}, \mathrm{C}(\mathrm{t})$ is $6.2 \mathrm{~kg} \mathrm{C}$ and the observed ${ }^{14} \mathrm{C}$ age is $c a .1 .8 \mathrm{ka}$, yielding an annual input of carbon to the $\mathrm{B}$ horizon of $c a .3 \mathrm{~g} \mathrm{C} \mathrm{m}^{-2} \mathrm{yr}^{-1}$.

The estimate of annual carbon input to the $\mathrm{B}$ horizon rests in part on the assumption that the organic matter in the B horizon is homogeneous with respect to decay. Although SOM is a mixture of compounds that accumulate and decay at different rates, evidence from leaching and fractionation support this assumption in the case of Spodosol B horizons. DOC leached from Harp Lake soil $\mathrm{B}$ horizons by acid hydrolysis was not greatly enriched in ${ }^{14} \mathrm{C}$ compared to residual SOM. Organic $\mathrm{C}$ solubilized from the $\mathrm{B} 1$ horizon by the neutral leach was enriched in ${ }^{14} \mathrm{C}$, but was $<0.02 \%$ of the total organic carbon in the layer. The ${ }^{14} \mathrm{C}$ content of the organic carbon in a Russian Spodosol collected before 1950 changed from a bulk $\Delta^{14} \mathrm{C}$ of $-250 \%$ to $-290 \%$ after hydrolysis in hot $6 \mathrm{~N} \mathrm{HCl}$ solubilized up to $90 \%$ of the organic carbon in the layer (Trumbore, Bonani \& Wölfli 1990). The lack of large differences in the ${ }^{14} \mathrm{C}$ contents of acid extracted and bulk SOM suggests a greater degree of homogeneity of organic matter in Spodosol B horizons than is observed in other soil orders (Trumbore, Bonani \& Wölfli 1990).

\section{Decomposition}

The combined loss of DOC through transport out of the watershed and sorption in soils is roughly $6 \mathrm{~g} \mathrm{C} \mathrm{m}^{-2} \mathrm{yr}^{-1}$. This is close to the minimum rate of DOC production estimated from bomb ${ }^{14} \mathrm{C}$ content of SOM, but smaller than the more realistic rates based on detrital inputs (ca. 200-350 $\mathrm{g}$ $\left.\mathrm{C} \mathrm{m}^{-2} \mathrm{yr}^{-1}\right)$. Thus, the largest sink for DOC is probably rapid decomposition in the soil.

\section{Origin of Groundwater and Stream DOC in Harp Lake Catchment}

The origin of the low concentrations and ${ }^{14} \mathrm{C}$ contents of DOC measured in shallow groundwaters are consistent with either: 1) origin of DOC (via SOM oxidation or desorption) in the soil B horizon, or in the aquifer; or 2) decomposition and/or sorption of more labile DOC as water percolates downward in the soil, leaving more refractory components. The similarity of groundwater DOC ${ }^{14} \mathrm{C}$ contents and those of acid leachates from soil $\mathrm{B}$ horizons raises the interesting question of whether DOC observed in the shallow groundwaters has been mobilized by acidification of the watershed, or whether it is representative of pre-anthropogenic conditions.

Two components contribute to determining the concentration and ${ }^{14} \mathrm{C}$ content of $\mathrm{DOC}$ in streams: the source of the water for stream generation, and the interaction of the source water with SOM. Studies using stable isotopes $\left({ }^{18} \mathrm{O}\right)$ at Harp 4 and Harp 4-21 have shown that groundwater is the 
main component of stream discharge during storm events (Bottomley, Craig \& Johnston 1984; Hinton, English \& Schiff 1991). Groundwater is also the source of streamwater during low-flow (summer) conditions. The leaching experiments reported here show that water flowing through the shallow part of the soil (litter and $\mathrm{A}$ horizons) should contain more $\mathrm{DOC}$ and $\mathrm{DO}^{14} \mathrm{C}$ than that flowing through deeper soil layers. Therefore, the observed differences in $\mathrm{DOC}$ and $\mathrm{DO}^{14} \mathrm{C}$ between streams and groundwaters must be due to interactions of groundwater with organic-rich soil layers close to the stream bed (the riparian zone; Fiebig, Lock \& Neal 1990). As the groundwater is characterized by low DOC content, even a small addition of DOC from shallow soil horizons would dominate the streamwater DOC concentration and ${ }^{14} \mathrm{C}$ content.

\section{CONCLUSIONS}

The concentration and carbon isotopic content of DOC in stream, soil and groundwater provide sensitive tools with which to study the complex interactions of water and soils in forested catchments. In the Litter and A horizons, DOC production in the watershed is balanced by in-situ decay, transport out of the watershed in streams and groundwater and sorption in the soil B horizon. Groundwater DOC characteristics are determined by processes in the soil column. The characteristics of DOC in streams depends on the flowpath of water through the soil prior to joining the stream.

Schiff et al. (1990) determined that the presence of significant bomb ${ }^{14} \mathrm{C}$ in stream DOC indicated that substantial portions turn over on decadal timescales. Thus, cycling of DOC may respond on the timescale of anthropogenic forcing, such as increased acidity in precipitation. The presence of ${ }^{14} \mathrm{C}$-depleted carbon indicates the cycling of 'old' organic matter may be a significant source of DOC, even in surface waters. Keller (1991) observed decreases in groundwater DIC due to remineralization of ${ }^{14} \mathrm{C}$-depleted organic matter which would normally be referred to as 'refractory'. Cycling of ${ }^{14} \mathrm{C}$-depleted organic carbon in mineral soils and aquifers will obviously pose problems for the use of $\mathrm{DO}^{14} \mathrm{C}$ and $\mathrm{DI}^{14} \mathrm{C}$ date groundwaters (Murphy et al. 1989; Wassenaar et al. 1991b; Keller 1991).

\section{ACKNOWLEDGMENTS}

This paper was written under the auspices of the U. S. Department of Energy by the Lawrence Livermore National Laboratory under contract number W-7405-Eng-48. This work was also supported by a grant from NSERC, Canada.

\section{REFERENCES}

Aravena, R. and Schiff, S. L. $1991 \mathrm{CO}_{2}$ production and carbon cycling in Precambrian Shield watersheds. In Proceedings of Environmental Research: 1991 Technology Transfer Conference, Environment Ontario: 22-30.

Aravena, R. Schiff, S. L., Trumbore, S. E., Dillon, P. J. and Elgood, R. 1992 Evaluating dissolved inorganic carbon cycling in a forested lake watershed using carbon isotopes. Radiocarbon, this issue.

Bottomley, D. J., Craig, D. and Johnston, L. M. 1984 Neutralization of acid runoff by groundwater discharge to streams in Canadian Precambrian Shield watersheds. Journal of Hydrology 75: 1-26.

Boutton, T. W., Wong, W. W., Hachey, D. L., Lee, L. S., Cabrera, M. P. and Klein, P. D. 1983 Compari- son of quartz and pyrex tubes for combustion of organic samples for stable carbon isotope analysis. Analytical Chemistry 55: 1832-1833.

Brady, N. C. 1983 The Nature and Properties of Soils. New York, Macmillan Publishing Company: 434463.

Chandler, R. F. 1942 The time required for Podzol profile formation as evidenced by the Mendenhall Glacial deposits near Juneau, Alaska. Soil Science Society of America Proceedings 7: 454-458.

Cronan, C. S. 1985 Comparative effects of precipitation acidity on three forest soils. Carbon cycling responses. Plant Soil 88: 101-112.

Dankevy, S. N., Schiff, S. L., English, M. C. and Dillon, P. J. 1990 Groundwater flow and chemistry 
in a small acid-stressed subcatchment in the Canadian Shield. In Proceedings of the NHRI Symposium on Groundwater Contamination. National Hydrologic Research Institute, Environment Canada, Saskatoon, Canada, in press.

Davis, J. C., Proctor, I. D., Southon, J. R., Caffee, M. W., Heikkinen, D. W., Roberts, M. L., Moore, T. L., Turteltaub, K. W., Nelson, D. E., Loyd, D. H. and Vogel, J. S. 1990 LLNL/UC AMS facility and research program. In Yiou, F. and Raisbeck, G. M., eds., Proceedings of the 5th International Conference on Accelerator Mass Spectrometry. Nuclear Instruments and Methods B52: 269-272.

Dawson, H. J., Ugolini, F. C. and Fasth, W. S. 1978 Role of soluble organics in the soil processes of a podzol, central Cascades, Washington. Soil Science 126: $290-296$

Fiebig, D. M., Lock, M. A. and Neal, C. 1990 Soil water in the riparian zone as a source of carbon for a headwater stream. Journal of Hydrology 116: 217-237.

Hinton, M. J., English, M. C. and Schiff, S. L. 1991 Tracing groundwater flow pathways in a head-water catchment and evaluating the implications for acidic precipitation research. Abstract. International Conference on Acidic Deposition: Its Nature and Impacts. Glasgow, Scotland: 379.

Jardine, P. M., Weber, N. L. and McCarthy, J. F. 1989 Mechanisms of dissolved organic carbon adsorption on soil. Soil Science Society of America Journal 53: 1378-1385.

Keller, C. K. 1991 Hydrogeochemistry of a clayey till, 2. Sources of $\mathrm{CO}_{2}$. Water Resources Research 27: 2555-2564.

LaZerte, B. D. and Dillon, P. J. 1984 Relative importance of anthropogenic versus natural sources of acidity in lakes and streams of Central Ontario. Canadian Journal of Fisheries and Aquatic Sciences 41: 1664-1677.

Murphy, E. M., Davis, S. N., Long, A., Donahue, D. and Jull, A. J. T. 1989 Characterization and isotopic composition of organic and inorganic carbon in the Milk River Aquifer. Water Resources Research 25: 1893-1905.

Nadelhoffer, K. J. and Fry, B. 1988 Controls on natural Nitrogen-15 and Carbon-13 abundances in forest soil organic matter. Soil Science Society of America Journal 52: 1633-1640.

Nodvin, S. C., Driscoll, C. T. and Likens, G. E. 1986
Simple partitioning of anions and dissolved organic carbon in a forest soil. Soil Science 142: 27-35.

Reiners, W. A. 1973 Terrestrial detritus and the carbon cycle. In Woodwell, G. M. and Pecan, E. V., eds., Proceedings of the 24th Brookhaven Symposium in Biology, Upton, NY. Atomic Energy Commission Symposium Series 30: 303-327.

Schiff, S. L., Aravena, R., Trumbore, S. E. and Dillon, P. J. 1990 Dissolved organic carbon cycling in forested watersheds: A carbon isotope approach. Water Resources Research 26: 2949-2957.

Stevenson, F. J. 1982 Humus Chemistry: Genesis, Composition, Reactions. Somerset, New Jersey, John Wiley \& Sons, Inc: Chapter 1.

Stuiver, M. and Polach, H. A. 1977 Discussion: Reporting of ${ }^{14} \mathrm{C}$ data. Radiocarbon 19(3): 355-363.

Trumbore, S. E., Bonani, G. and Wölfli, W. 1990 The rates of carbon cycling in several soils from AMS ${ }^{14} \mathrm{C}$ measurements of fractionated soil organic matter. In Bouwman, A. F., ed., Soils and the Greenhouse Effect, Chichester, UK, John Wiley \& Sons, Ltd.: 405-414.

Vance, G. F. and David, M. B. 1991 Forest soil response to acid and salt additions of sulfate: III. Solubilization and composition of dissolved organic carbon. Soil Science 151: 297-305.

Vogel, J. S., Nelson, D. E. and Southon, J. R. $1987{ }^{14} \mathrm{C}$ background levels in an accelerator mass spectrometry system. Radiocarbon 29(3): 323-333.

Wassenaar, L. I., Aravena, R., Fritz, P. and Barker, J. F. 1991a Controls on the transport and carbon isotopic composition of dissolved organic carbon in a shallow groundwater system, Central Ontario. Chemical Geology 87: 39-57.

Wassenaar, L. I., Aravena, R., Hendry, M. J. and Fritz, P. 1991b Radiocarbon in dissolved organic carbon a potential groundwater dating method: Case studies from western Canada. Water Resources Research 27: 1975-1986.

Wassenaar, L. I., Hendry, M. J., Aravena, R. and Fritz, P. 1990 Organic carbon isotope geochemistry of clayey deposits and their associated porewaters, Southern Alberta. Journal of Hydrology 120: 251270

Zinke, P. J. Stangenberger, A. G., Post, W. M., Emanual, W. R. and Olson, J. S. 1984 Worldwide organic soil carbon and nitrogen data. Environmental Science Division Publication 2212. Oak Ridge National Laboratory: $141 \mathrm{p}$. 